\title{
Propofol specifically suppresses IL-1 $\beta$ secretion but increases bacterial survival in Staphylococcus aureus-infected RAW264.7 cells
}

\author{
Ming-Shan Chen ${ }^{1} \cdot$ Wen-Chun $\operatorname{Lin}^{2} \cdot$ Hsuan-Te Yeh ${ }^{1} \cdot$ Chia-Lin Hu ${ }^{1} \cdot$ Shew-Meei Sheu ${ }^{2,3}$ (D)
}

Received: 25 October 2017 / Accepted: 5 April 2018 / Published online: 17 April 2018

(C) The Author(s) 2018

\begin{abstract}
Anesthetics have immunomodulatory effects, but the use of different assay systems has contributed to inconsistent results in the literature. IL-1 $\beta$ and reactive oxygen species (ROS) secreted by phagocytes are important factors that protect against Staphylococcus aureus infection. In this study, the effects of four intravenous anesthetics (propofol, thiamylal sodium, midazolam, and ketamine) on IL- $1 \beta$ secretion, ROS, and bacterial survival in S. aureus-infected RAW264.7 cells were evaluated. S. aureus-infected RAW264.7 cells with or without intravenous anesthetic treatment were established as the experimental model. Cell supernatants were subjected to ELISAs to measure secreted IL-1 $\beta$. Cell pellets were subjected to qPCR and western blot analyses to analyze IL- $1 \beta$ mRNA and protein levels. Luminol chemiluminescence assays were used to detect ROS, and bacterial survival was determined by counting the colony forming units at the beginning and end of the infection. Compared with the levels after treatment with the other intravenous anesthetics, secreted IL- $1 \beta$ levels were lowest in the supernatant of $S$. aureus-infected RAW264.7 cell cultures after propofol treatment, but propofol did not decrease IL-1 $\beta$ mRNA or protein expression. However, thiamylal sodium and midazolam decreased IL-1 $\beta$ mRNA and protein expression in a dose-dependent manner. Additionally, propofol substantially decreased S. aureus-stimulated ROS and phagocytosis. Bacterial survival was strongly increased by propofol treatment. Of the four intravenous anesthetics, propofol was the most potent inhibitor of IL-1 $\beta$ secretion and ROS level in S. aureus-infected RAW264.7 cells; moreover, propofol resulted in an increase in bacterial survival by inhibiting ROS and phagocytosis.
\end{abstract}

Keywords Intravenous anesthetics $\cdot$ Propofol $\cdot$ S. aureus $\cdot \mathrm{IL}-1 \beta \cdot \mathrm{ROS}$

\section{Introduction}

Intravenous anesthetics may be used for the sedation of perioperative and critically ill patients but also have potential immunomodulatory effects [1-3]. Intravenous anesthetics can inhibit human phagocyte functions, including chemotaxis, cytokine secretion, phagocytosis, and reactive oxygen species (ROS) generation [1, 4-8]. The disruption of any phagocyte function could result in bacterial infections.

Shew-Meei Sheu

cych12554@gmail.com

1 Department of Anesthesiology, Ditmanson Medical Foundation Chia-Yi Christian Hospital, Chia-Yi, Taiwan

2 Department of Medical Research, Ditmanson Medical Foundation Chia-Yi Christian Hospital, Chia-Yi, Taiwan

3 Department of Medical Laboratory Science and Biotechnology, Chung Hwa University of Medical Technology, Tainan, Taiwan
Staphylococcus aureus is one of the most important pathogens that cause human morbidity and mortality worldwide [9]. S. aureus can lead to various infections ranging from minor skin and soft tissue infections to life-threatening invasive diseases, such as necrotizing pneumonia and sepsis [9-11]. S. aureus acts via several mechanisms to escape host immune defenses and establish an infection, including resisting antimicrobial peptides, clearing ROS, inhibiting complement activation and neutrophil recruitment, and evading phagocytosis $[12,13]$.

Among host defense mechanisms, IL- $1 \beta$ secreted by phagocytes is important in protecting against $S$. aureus infections. IL-1 $\beta$-deficient mice have demonstrated the importance of IL-1 $\beta$ in neutrophil infiltration and deep $S$. aureus skin infections $[14,15]$. Two major steps are involved in IL- $1 \beta$ secretion. First, the expression of proIL- $1 \beta$ is induced by microbial components. Second, the IL-1 $\beta$ precursor $(34 \mathrm{kDa})$ is cleaved into its mature form $(17 \mathrm{kDa})$ by inflammasome-activated caspase 1 or 
released through an unknown caspase 1-independent pathway [16]. Previous papers have shown that propofol can decrease IL-1 $\beta$ secretion in macrophages [17] and that several general anesthetics inhibit IL- $1 \beta$ mRNA expression in LPS-stimulated glial cells and primary microglia $[18,19]$. However, the regulatory mechanisms of intravenous anesthetics regarding IL- $1 \beta$ secretion remain unclear.

Although intravenous anesthetics may have immunomodulatory effects, the literature is controversial. For example, propofol has been shown to significantly reduce chemotaxis, phagocytosis, and ROS production in macrophages [7,8], but these results are not consistent with the studies from Ploppa et al. [20, 21]. The use of different assay systems might contribute to these discrepancies. Therefore, we used one system, S. aureus-infected RAW264.7 cells, to compare the effects of four intravenous anesthetics on IL- $1 \beta$ secretion, ROS levels, and bacterial survival.

\section{Materials and methods}

\section{Bacteria, cell culture, and bacterial infection}

S. aureus ATCC 25923 was grown on blood agar (tryptic soy agar with 5\% sheep blood) and sub-cultured in Luria-Ber$\operatorname{tani}(\mathrm{LB})$ broth for $16 \mathrm{~h}$ for the infection assay. The mouse macrophage cell line RAW264.7 was purchased from the Food Industry Research and Development Institute in Taiwan. The cells were grown in DMEM (Gibco BRL, Grand Island, NY, USA) containing 10\% FBS and were sub-cultured every 2-3 days. To conduct the $S$. aureus infection assays, a 10 -fold dilution of bacteria (OD $600=1)$ was added to RAW264.7 cells for a 30-min incubation. Next, free bacteria were washed away with $1 \times$ PBS, and a multiplicity of infection (MOI) of 15 was established; DMEM supplemented with $2 \%$ FBS was then added for incubation and further analyses.

\section{Reagents}

Propofol lipid emulsion, thiamylal sodium, midazolam, and ketamine were purchased from Fresenius Kabi Austria GmbH (Graz, Austria), Shinlin Sinseng Pharmaceutical Co., Ltd. (Taoyuan, Taiwan), Nang Kuang (Tainan, Taiwan), and Taiwan Pfizer Inc. (New Taipei, Taiwan), respectively. The NADPH oxidase inhibitor diphenyleneiodonium chloride (DPI) purchased from Abcam (ab141310, Cambridge, UK) was used to inhibit ROS production.

\section{Cytotoxicity assay}

The lactate dehydrogenase (LDH) activity present in lysed RAW264.7 cells infected with $S$. aureus and treated with or without intravenous anesthetics was determined using a Cytotoxicity Detection Kit ${ }^{\text {PLUS }}$ (Roche Applied Science, Mannheim, Germany), according to the manufacturer's instructions.

\section{Viability assay}

Cell counting kit-8 (Sigma-Aldrich, Inc., St. Louis, MO, USA) assays were used to evaluate cell viability. The adjusted concentrations of intravenous anesthetics used for the cell viability assay were based on the clinically relevant concentrations of propofol $(6 \mu \mathrm{g} / \mathrm{ml})$, thiamylal sodium $(30 \mu \mathrm{g} / \mathrm{ml})$, midazolam $(1.5 \mu \mathrm{g} / \mathrm{ml})$, and ketamine $(2 \mu \mathrm{g} / \mathrm{ml})$; these concentrations are in accordance with the typical therapeutic doses given by intravenous injection to adult patients. RAW264.7 cells $\left(1 \times 10^{5}\right.$ cells/ well) suspended in DMEM with $10 \%$ FBS were seeded in a 96-well microplate and incubated overnight. After adherence, the cells were treated with one, two, or five times the clinically relevant concentrations of intravenous anesthetics for $5 \mathrm{~h}$ and were then washed 3 times with $1 \times$ PBS. Then, cell medium containing a WST-8 solution was added for up to $2 \mathrm{~h}$ to measure the metabolically active cells. Finally, cell viability was measured using a Model 680 microplate reader (absorbance at $450 \mathrm{~nm}$; reference at $655 \mathrm{~nm}$ ) (Bio-Rad Laboratories, Inc., Hercules, CA, USA). The cell viability was calculated using the following formula: $A_{\text {treated }} / A_{\text {control }}$.

\section{Intravenous anesthetic treatment of $S$. aureus-infected RAW264.7 cells}

RAW264.7 cells were preincubated with the intravenous anesthetics for $30 \mathrm{~min}$ and then infected with $S$. aureus suspended in medium containing the same concentrations of intravenous anesthetics for $30 \mathrm{~min}$. After the incubation period, the cells were washed with $1 \times$ PBS, and the same concentrations of intravenous anesthetics were added again; the time of this addition served as the starting time point $(0 \mathrm{~h})$. RAW264.7 cells and $S$. aureus-infected RAW264.7 cells treated without intravenous anesthetic served as the negative and positive controls, respectively. For this infection model, IL-1 $\beta$ mRNA and protein expression levels were determined using cell pellets collected at $3 \mathrm{~h}$ from 6 -well plates $\left(1 \times 10^{6}\right.$ cells/well $)$, whereas IL-1 $\beta$ secretion was assayed using supernatants sampled 
at $4 \mathrm{~h}$ from a 96 -well microplate $\left(1 \times 10^{5}\right.$ cells/well $)$; these supernatants were assayed using a mouse IL-1 $\beta$ ELISA kit (Elabscience, Houston, Texas, USA), according to the manufacturer's instructions.

\section{Quantitative polymerase chain reaction}

Total RNA was isolated using Trizol reagent (Invitrogen Corporation, Carlsbad, CA, USA) according to the manufacturer's procedures. The concentration and integrity of the total RNA were evaluated based on the A260/280 ratio. mRNA levels were quantified using the SuperScript ${ }^{\mathrm{TM}}$ III Platinum $^{\text {TM }}$ One-Step qRT-PCR Kit (Thermo Fisher Scientific Inc., Carlsbad, CA, USA) and the TaqMan probes and primers for GAPDH (Mm99999915_g1) and customized IL-1 $\beta$ probes and primers (primers: forward: $5^{\prime}$ GTC CTGATGAGAGCATCCAG3', reverse: 5'CGGGAAAGA CACAGGTAGC3'; probe: TCGCAGCAGCACATCAAC AAGAGC). Quantitative polymerase chain reaction (qPCR) assays were performed using the CFX96 ${ }^{\mathrm{TM}}$ Real-Time PCR Detection System (Bio-Rad Laboratories, Inc., Foster, CA, USA). IL-1 $\beta$ gene expression was normalized to GAPDH and shown as the fold change relative to the control cells.

\section{Western blot analysis}

Cells were lysed with M-PER mammalian protein extraction reagent (Thermo Scientific Inc., Rockford, IL, USA) containing $0.1 \%$ protease inhibitor cocktail. Equal amounts (40 $\mu \mathrm{g})$ of samples were run on SDS-PAGE gels and transferred to PVDF membranes. The membranes were then incubated with anti-mouse IL-1ß/IL-1F2 (R\&D Systems, Inc., Minneapolis, MN, USA) and anti-GAPDH (GeneTex, Inc., Irvine, CA, USA) antibodies, followed by incubation with secondary antibodies conjugated to horseradish peroxidase (HRP). After incubation with Immobilon Western Chemiluminescent HRP substrate (EMD Millipore Corporation, Billerica, MA, USA), the signals were detected using the BioSpectrum Imaging System (UVP).

\section{Luminol chemiluminescence assay}

Luminol (5-amino-2,3-dihydro-1,4-phthalazinedione) freely permeates through the cell membrane and was used to detect the total amount of intracellular and extracellular ROS produced by NADPH oxidase. RAW264.7 cells $\left(1 \times 10^{5}\right.$ cells/ well) were preincubated with intravenous anesthetics in a 96-well white microplate for $30 \mathrm{~min}$; then, $S$. aureus with the same concentrations of intravenous anesthetics were added to the cells for $30 \mathrm{~min}$. After washing twice with $1 \times$ PBS, the cells were stained with $0.05 \mathrm{mg} / \mathrm{ml}$ luminol (Sigma-Aldrich, Inc., St. Louis, MO, USA). The increase in the chemiluminescence resulting from ROS production was measured immediately and was analyzed continuously over $1 \mathrm{~h}$ at $37^{\circ} \mathrm{C}$ using a BioTek Synergy $\mathrm{H} 1$ microplate reader (BioTek, Winooski, VT, USA). RAW264.7 cells that were not preincubated with intravenous anesthetics but with $S$. aureus incubation were used as a positive control. Treatment with each intravenous anesthetic alone was also used as a control. The peak value of chemiluminescence at $5 \mathrm{~min}$ was used to calculate the relative effect of the intravenous anesthetics on ROS production.

\section{Bacterial survival assay}

Bacterial survival assays were conducted on RAW264.7 cells that had undergone intravenous anesthetic pretreatment and were then infected with $S$. aureus and incubated with intravenous anesthetics. Moreover, cells infected with $S$. aureus but without intravenous anesthetic treatment were used as a reference control. Each infection condition occupied two wells, allowing the bacteria to be counted at two time points $(0$ and $3 \mathrm{~h})$. The first well contained cells that were infected with $S$. aureus for $30 \mathrm{~min}$ and then washed with $1 \times$ PBS $(0 \mathrm{~h})$. The second well had the same conditions as the first well, but the cells were further incubated for $3 \mathrm{~h}$. Finally, the cell suspensions were serially diluted, and these dilutions were plated on LB agar plates. Colony forming units (CFU) were counted the following day, and changes in bacterial survival were calculated as the CFU at $3 / 0 \mathrm{~h}$.

\section{Phagocytosis of S. aureus bioparticles}

Phagocytosis was assessed using pHrodo ${ }^{\mathrm{TM}}$ Green $S$. aureus Bioparticles ${ }^{\circledR}$ Conjugate (P35367, Life technologies, Carlsbad, CA, USA), according to the manufacturer's instructions. These $S$. aureus particles were conjugated to $\mathrm{pHrodo}^{\mathrm{TM}}$ dye, which dramatically increases green fluorescence at an acidic $\mathrm{pH}$, and were suitable for quantitative measurements of phagocytosis. RAW264.7 cells were suspended in Opti-MEM ${ }^{\circledR}$, seeded in a 96-well plate $\left(1 \times 10^{5}\right.$ cells/well) and incubated overnight. pHrodo $S$. aureus bioparticles conjugates were resuspended in Live Cell Imaging Solution $(1 \mathrm{mg} / \mathrm{ml})$. The cells in experimental wells were pretreated with propofol or cytochalasin D for $30 \mathrm{~min}$, and then, pHrodo $S$. aureus particles combined with or without propofol were added to the cells. The positive control was the cells treated only with $S$. aureus particles without pretreatment. The plates were covered and incubated at $37^{\circ} \mathrm{C}$ for $2 \mathrm{~h}$ in the absence of $\mathrm{CO}_{2}$. Fluorescence was recorded using a BioTek Synergy H1 microplate reader (BioTek, Winooski, VT, USA) with 490-nm excitation and 540-nm emission wavelengths. Additionally, the cells that had been incubated with $S$. aureus particles were stained with Hoechst 33342 or LysoTracker Red DND-99 (Invitrogen Life Technologies, CA, USA) to label acidified compartments 
for live cell imaging. Fluorescence microscopy (Olympus Corporation, Tokyo, Japan) was used to visually investigate phagocytosis.

\section{Results}

\section{S. aureus induced IL-1 $\beta$ secretion in RAW264.7 cells}

Staphylococcus aureus slightly induced intracellular pro$\mathrm{IL}-1 \beta$ at $2 \mathrm{~h}$, and these levels increased dramatically at $3 \mathrm{~h}$ (Fig. 1a). In the supernatant of this infection condition, secreted IL- $1 \beta$ was detectable at $2 \mathrm{~h}$ and increased in a timedependent manner (Fig. 1b). To exclude IL- $1 \beta$ secretion due to cell lysis, we measured LDH activity at different time points. A high percentage (32.8\%) of cell death occurred at $6 \mathrm{~h}$ (Fig. 1c). Therefore, the maximum time for sample collection was set at $4 \mathrm{~h}$.

\section{Intravenous anesthetics decreased IL-1 $\beta$ secretion}

Cell viability after treatment with one, two, and five times the clinically relevant concentrations of intravenous anesthetics was investigated to avoid cytotoxicity in RAW264.7 cells. Propofol (12 and $30 \mu \mathrm{g} / \mathrm{ml})$ treatment decreased cell viability by $>40 \%$. However, the viability remained as high as $90 \%$ when the cells were treated with one or two times the clinically relevant concentrations of the other three intravenous a

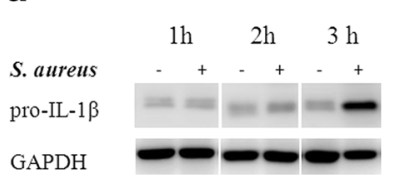

C

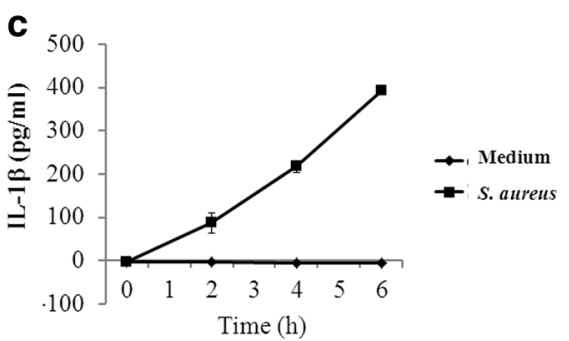

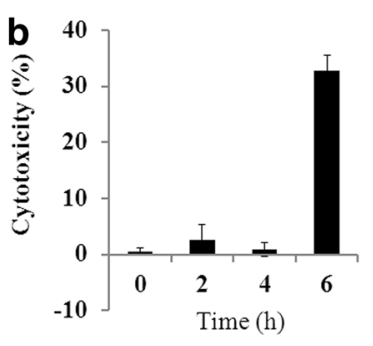

Fig. 1 Kinetics of the production and secretion of IL-1 $\beta$ in S. aureusinfected RAW264.7 cells. RAW264.7 cells were co-cultured with $S$. aureus for different periods of time. a Western blot of intracellular pro-IL- $1 \beta$ at the indicated times. b IL- $1 \beta$ secretion at 2,4 , and $6 \mathrm{~h}$ was measured by ELISA. c Cell cytotoxicity was measured by LDH release and is shown as a percentage relative to the total cell lysis after Triton X-100 detergent treatment. The data obtained from three individual experiments are expressed as the means $\pm \mathrm{SD}$ anesthetics (Fig. 2a). Next, we investigated whether intravenous anesthetics decrease IL-1 $\beta$ secretion in RAW264.7 cells infected with $S$. aureus. The lowest level of secreted IL-1 $\beta$ was detected with propofol treatment of the $S$. aureus-infected RAW264.7 cells (Fig. 2b). Secreted IL- $1 \beta$ also decreased following treatment with thiamylal sodium, midazolam, and ketamine, but treatment at higher concentrations (two times the clinically relevant concentrations) did not further decrease the IL- $1 \beta$ secretion. LDH activity was also examined to confirm that cell death was rare for each infection condition; this was the case for each infection condition except the treatment with $12 \mu \mathrm{g} / \mathrm{ml}$ propofol (Fig. 2c). The NADPH oxidase inhibitor DPI blocked IL-1 $\beta$ secretion (Fig. $2 b$ ).

\section{Thiamylal sodium and midazolam inhibited IL-1 $\beta$ mRNA and pro-IL-1 $\beta$ synthesis}

We next determined whether intravenous anesthetics decreased the expression of IL- $1 \beta$ mRNA and protein; thiamylal sodium and midazolam treatment inhibited IL- $1 \beta$ mRNA and pro-IL-1 $\beta$ expression in a dose-dependent manner (Fig. 3a, b). In contrast, propofol did not cause similar effects, and ketamine increased IL- $1 \beta$ mRNA and pro-IL- $1 \beta$ expression (Fig. 3a, b). DPI strongly inhibited IL-1 $\beta$ mRNA $(80 \%)$ and pro-IL-1 $\beta$ production.

\section{S. aureus-induced ROS production and bacterial survival were modulated by intravenous anesthetics}

In the $S$. aureus-infected RAW264.7 cells, ROS level was significantly inhibited by three of the intravenous anesthetics: propofol, thiamylal sodium, and ketamine (Fig. 4a). Of these treatments, propofol yielded the lowest ROS level, and the clinically relevant concentration of propofol reduced ROS level by $>50 \%$. To confirm $S$. aureus survival during infection along with intravenous anesthetic treatment, we assessed the cell-associated bacterial number after $30 \mathrm{~min}$ of infection as the starting time point. At this time point, similar bacterial numbers were found for RAW264.7 cells receiving the different intravenous anesthetic treatments (Fig. 4b). Three hours later, the bacterial number was significantly increased in $S$. aureus-infected RAW264.7 cells that received propofol treatment. The other intravenous anesthetics did not affect bacterial survival compared with the untreated $S$. aureus-infected cells (Fig. 4c). We further examined whether propofol promoted bacterial survival by minimizing the phagocytic ability and found that propofol actually inhibited the phagocytosis of $S$. aureus BioParticles (Fig. 5a). The amount of green $S$. aureus was substantially decreased in the RAW264.7 cells with propofol treatment, similar to the results with the anti-phagocytosis effector cytochalasin D (Fig. 5b). S. aureus bioparticles exhibited colocalization with the LysoTracker label in RAW264.7 cells with or without propofol treatment (Fig. 5c). 


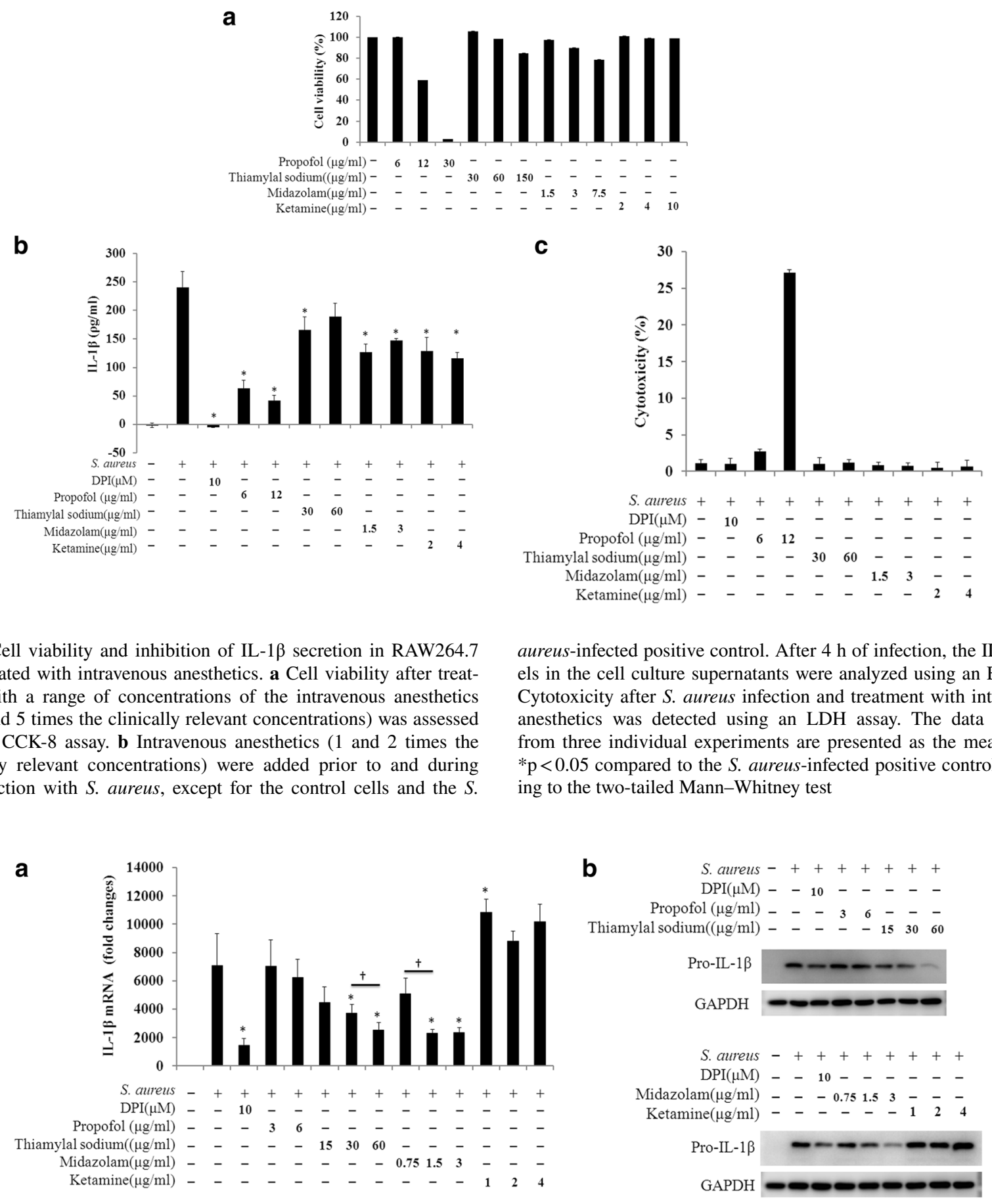

Fig. 3 IL- $1 \beta$ mRNA and pro-IL-1 $\beta$ biosynthesis modulation by intravenous anesthetics. RAW264.7 cells $\left(1 \times 10^{6} /\right.$ well $)$ were exposed to media only or $S$. aureus in the absence or presence of intravenous anesthetics for $3 \mathrm{~h}$. a IL- $1 \beta$ mRNA was detected by a qPCR assay. The data are presented as the fold change versus the control cells; the data were obtained from three individual experiments. * indicates a significant difference compared to the $S$. aureus-infected positive con- trol using the two-tailed Mann-Whitney test $(\mathrm{p}<0.05) . \dagger$ indicates a significant difference between the two marked groups. b Pro-IL-1 $\beta$ biosynthesis was measured via western blot analysis. One set of representative data obtained from three individual experiments is presented. The experiments were performed using $0.5,1$, and 2 times the clinically relevant concentrations of the anesthetics, but propofol was used at only 0.5 and 1 times its clinically relevant concentration 
Fig. 4 Effect of intravenous anesthetics on ROS level and bacterial survival. a Intravenous anesthetics suppressed $S$. aureus-induced ROS. RAW264.7 cells were incubated in the absence or presence of intravenous anesthetics prior to and during the infection with $S$. aureus. Treatment with $10 \mu \mathrm{M}$ DPI was used to inhibit ROS as a control. For the positive control, the maximum luminescence produced upon $S$. aureus infection was used as the reference value. The relative ratio was calculated from the luminescence value induced by co-incubation with a drug and the bacteria subtracted from the drug control and then divided by the luminescence of the positive control. A range of concentrations $(0.5,1$, and 2 times the clinically relevant concentrations) of intravenous anesthetics was used, except for propofol (for which 0.5 and 1 times the clinically relevant concentration were used). The data are presented as the means \pm SD of three replicates. b Similar cell-associated bacterial numbers with different intravenous anesthetic treatments. After incubation with $S$. aureus without or with intravenous anesthetics for $30 \mathrm{~min}$, RAW264.7 cells were washed and then suspended for growth and counting of the cell-associated colony forming units (CFUs) that started the infection $(0 \mathrm{~h})$. Intravenous anesthetics were used at their clinically relevant concentrations. c Propofol treatment increased $S$. aureus survival. Bacterial CFUs were grown and counted at the end of infection $(3 \mathrm{~h})$. Fold changes in bacterial survival were calculated based on the bacterial number at $3 \mathrm{~h}$ divided by the bacterial number at $0 \mathrm{~h}$. The data are presented as the means $\pm \mathrm{SD}$ of three individual experiments. Significance was analyzed using the two-tailed Mann-Whitney test $(\mathrm{p}<0.05) . *$ indicates a significant difference compared with the $S$. aureus-infected control

\section{Discussion}

Staphylococcus aureus infections cause various clinical pathological changes, from skin infection to severe sepsis, and macrophages play important roles in controlling these infections. Previous papers have demonstrated that anesthetics can inhibit several functions of phagocytes, including chemotaxis, phagocytosis, and ROS generation [1, 4-8]. Comparing the effects of different anesthetics on immunomodulation could result in information beneficial for choosing a clinical anesthetic. In this study, we used a model of $S$. aureus-infected RAW264.7 cells and found that of four intravenous anesthetics, propofol was the most effective agent for inhibiting IL- $1 \beta$ secretion, but this anesthetic did not decrease IL-1 $\beta$ mRNA or pro-IL- $1 \beta$ biosynthesis. Although thiamylal sodium and midazolam caused a dose-dependent decrease in IL- $1 \beta$ mRNA and pro-IL- $1 \beta$ biosynthesis, the suppression of IL- $1 \beta$ secretion by these agents was modest. Propofol also considerably reduced $S$. aureus-induced ROS production, and compared with $S$. aureus-infected RAW264.7 cells alone or with treatment with the other intravenous anesthetics, only propofol resulted in increased bacterial survival.

Chen et al. [17] demonstrated that RAW264.7 cells released the highest level of IL-1 $\beta(50 \mathrm{pg} / \mathrm{ml})$ after LPS stimulation for $6 \mathrm{~h}$. In this study, we used live $S$. aureus to cause an acute infection, and the RAW264.7 cells secreted up to $250 \mathrm{pg} / \mathrm{ml}$ of IL- $1 \beta$ at $4 \mathrm{~h}$. These results indicate that RAW264.7 cells are sensitive to $S$. aureus infection and that this model can be used to study IL- $1 \beta$ secretion. Live a

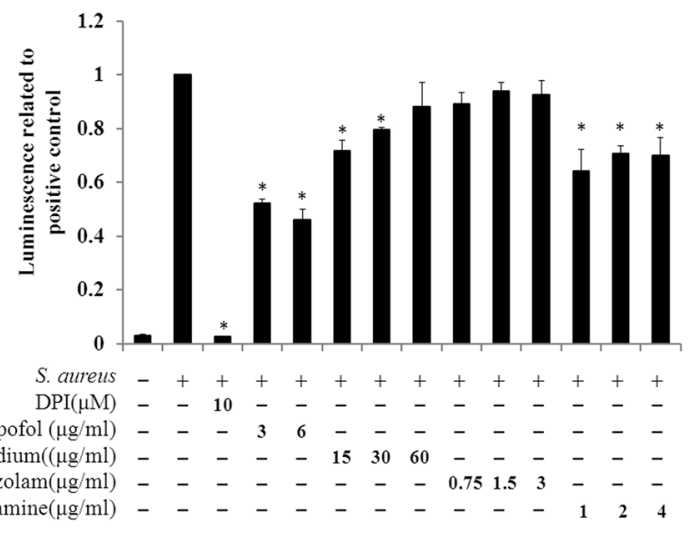

b

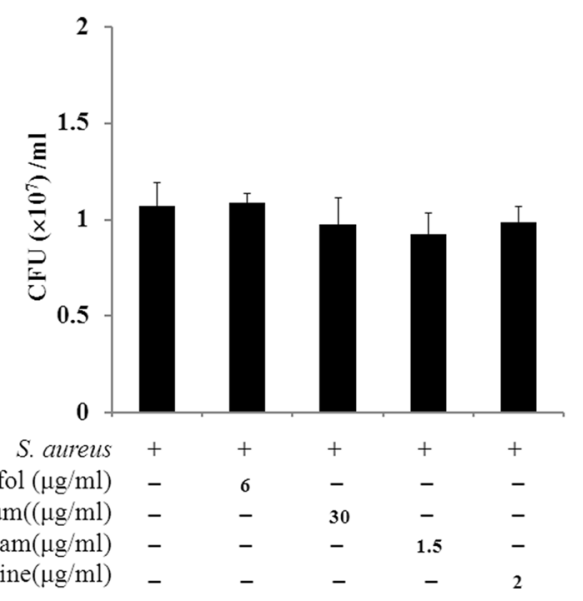

C

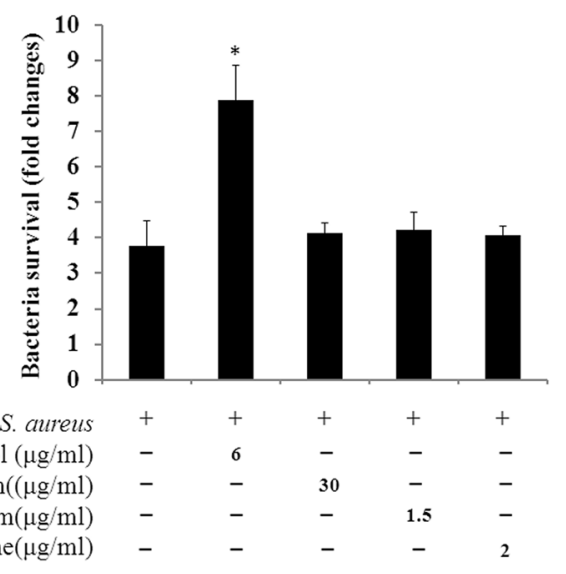

bacteria can also cause direct interactions between bacteria and cells.

Previous papers have revealed that propofol can reduce superoxide generation and elastase release in fMLF-activated human neutrophils, as well as polymorphonuclear leukocyte (PMNL) chemotaxis and cytokine secretion in LPS-activated macrophages [1, 17, 22]. In Fig. 2b, propofol considerably reduced IL- $1 \beta$ secretion. This result is consistent with a previous study using LPS-activated macrophages [17]. Studies related to the effects of the other intravenous anesthetics on macrophage-secreted IL- $1 \beta$ are limited, but a 
b

b $\begin{array}{r}\text { S. aureus + } \\ \text { Propofol }(\mu \mathrm{g} / \mathrm{ml}) \text { - } \\ \text { Cytochalasin } \mathrm{D}(\mu \mathrm{M}) \text { - }\end{array}$
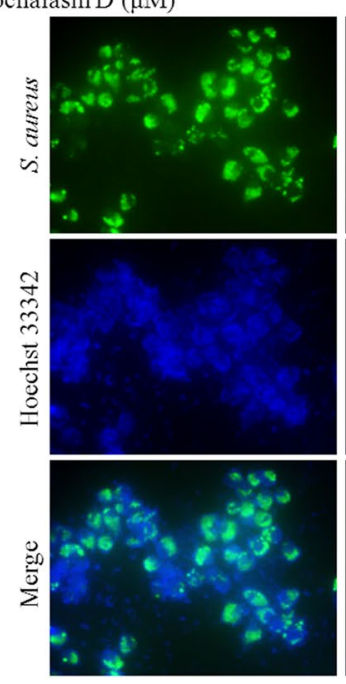

a

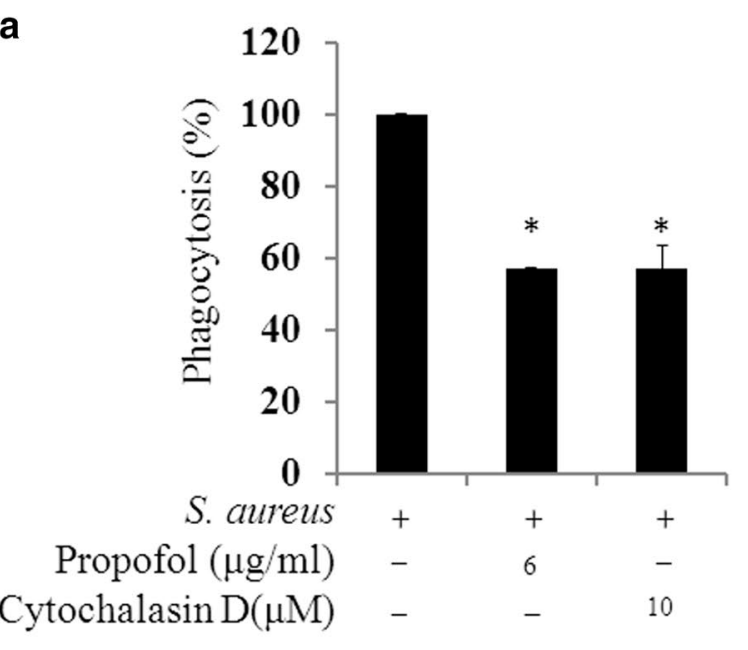




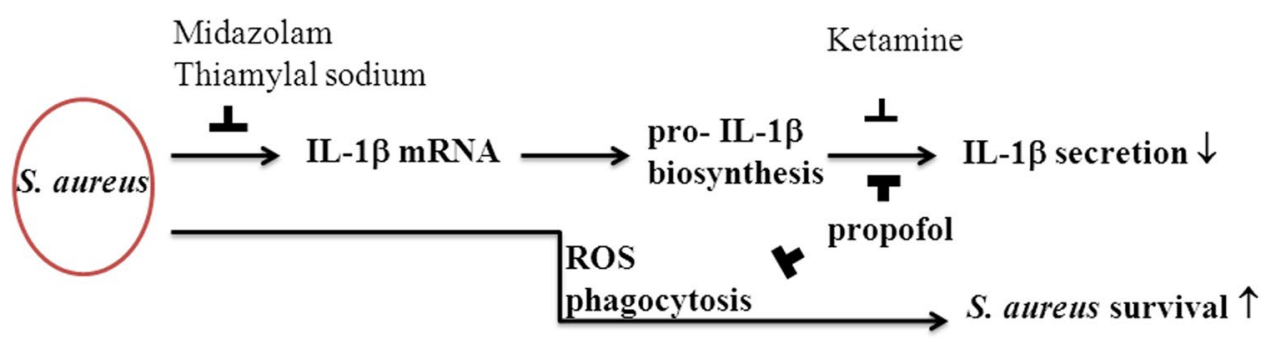

Fig. 6 The main effects of four intravenous anesthetics on IL-1 $\beta$ secretion and $S$. aureus survival. Midazolam and thiamylal sodium primarily inhibited pro-IL-1 $\beta$ mRNA and biosynthesis. Propofol and

propofol but was increased by ketamine treatment (Fig. 3a); these results are consistent with IL-1 $\beta$ biosynthesis (Fig. 3b). The discrepancy between previous studies and our study may be due to the diverse stimulants (LPS and S. aureus) and the different mechanisms regulating IL- $1 \beta$ mRNA. Additionally, exposure to thiamylal sodium and midazolam inhibited IL- $1 \beta$ mRNA and pro-IL- $1 \beta$ biosynthesis in a dose-dependent manner (Fig. 3a, b), but the suppression of IL-1 $\beta$ secretion by these agents was modest (Fig. 2b). Moreover, DPI treatment induced less pro-IL- $1 \beta$ synthesis but completely blocked IL-1 $\beta$ secretion (Figs. 3b, 2b). These results support the conclusion that posttranslational regulation is the critical step for controlling IL-1 $\beta$ secretion [23]. We also hypothesized that propofol and ketamine decreased IL-1 $\beta$ secretion via this mechanism because these two anesthetics did not decrease pro-IL-1 $\beta$ mRNA or protein biosynthesis (Fig. 3a, b).

In this study, the administration of DPI (an ROS inhibitor) to $S$. aureus-infected macrophages resulted in decreased IL- $1 \beta$ mRNA and pro-IL-1 $\beta$ synthesis (Fig. $3 a, b$ ); these results confirmed those of Tassi et al. [23]. ROS can induce $\mathrm{NF}-\mathrm{\kappa B}$ activation; NF- $\mathrm{KB}$ is one of the factors required for the transcription of proinflammatory cytokines, including IL-1 $\beta[24,25]$. Propofol, midazolam, and ketamine have been demonstrated to suppress ROS production in phagocytes $[1,6,26]$. Of the intravenous anesthetics used in this study, propofol was the best at reducing $S$. aureus-induced ROS levels (Fig. 4a). However, propofol did not affect IL-1 $\beta$ transcription (Fig. 3a). The effects of thiamylal sodium and midazolam on suppressing ROS levels were less than those of propofol, but thiamylal sodium and midazolam significantly inhibited IL-1 $\beta$ mRNA expression (Fig. 3a). These results suggest that ROS was not the only determinant factor in the regulation of IL-1 $\beta$ mRNA in our assay system.

Bacterial survival was particularly increased when the $S$. aureus-infected macrophages were treated with propofol (Fig. 4c). Propofol did not influence the cell-associated bacterial number at the beginning of infection (Fig. 4b) and bacterial growth (data not shown). Phagocytosis and ROS are critical for controlling bacterial infections. In our ketamine resulted in a decrease in IL-1 $\beta$ secretion. Moreover, propofol particularly increased $S$. aureus survival by suppressing ROS and phagocytosis

study, propofol significantly inhibited the ROS level and phagocytic ability (Figs. 4a, 5a, b) but not the formation of acidified compartments (Fig. 5c). These results provide direct evidence for the anti-phagocytic effects of propofol on S. aureus, which indicate that propofol contributes to the increase in bacterial survival due to the inhibition of ROS and phagocytosis.

\section{Conclusions}

Among the four intravenous anesthetics, thiamylal sodium and midazolam inhibited pro-IL- $1 \beta$ mRNA in a dosedependent manner in the $S$. aureus-infected RAW264.7 cells; however, propofol was the most effective at inhibiting the macrophage functions of IL- $1 \beta$ secretion and ROS level and did not decrease pro-IL-1 $\beta$ biosynthesis. Moreover, propofol increased bacterial survival though the suppression of ROS and phagocytosis (Fig. 6).

Acknowledgements This work was supported by the Ditmanson Medical Foundation of Chia-Yi Christian Hospital under Grant Number 105-17.

\section{Compliance with ethical standards}

Conflict of interest The authors report that no potential conflicts of interest exist.

Open Access This article is distributed under the terms of the Creative Commons Attribution 4.0 International License (http://creativeco mmons.org/licenses/by/4.0/), which permits unrestricted use, distribution, and reproduction in any medium, provided you give appropriate credit to the original author(s) and the source, provide a link to the Creative Commons license, and indicate if changes were made.

\section{References}

1. Yang SC, Chung PJ, Ho CM, Kuo CY, Hung MF, Huang YT, Chang WY, Chang YW, Chan KH, Hwang TL (2013) Propofol 
inhibits superoxide production, elastase release, and chemotaxis in formyl peptide-activated human neutrophils by blocking formyl peptide receptor 1. J Immunol 190(12):6511-6519. https://doi. org/10.4049/jimmunol.1202215

2. Davidson JA, Boom SJ, Pearsall FJ, Zhang P, Ramsay G (1995) Comparison of the effects of four i.v. anaesthetic agents on polymorphonuclear leucocyte function. Br J Anaesth 74(3):315-318

3. Helmy SA, Al-Attiyah RJ (2001) The immunomodulatory effects of prolonged intravenous infusion of propofol versus midazolam in critically ill surgical patients. Anaesthesia 56(1):4-8

4. Nagata T, Kansha M, Irita K, Takahashi S (2001) Propofol inhibits FMLP-stimulated phosphorylation of p42 mitogen-activated protein kinase and chemotaxis in human neutrophils. Br J Anaesth 86(6):853-858

5. Krumholz W, Endrass J, Hempelmann G (1995) Inhibition of phagocytosis and killing of bacteria by anaesthetic agents in vitro. Br J Anaesth 75(1):66-70

6. Chang Y, Chen TL, Sheu JR, Chen RM (2005) Suppressive effects of ketamine on macrophage functions. Toxicol Appl Pharmacol 204(1):27-35. https://doi.org/10.1016/j.taap.2004.08.011

7. Chen RM, Wu CH, Chang HC, Wu GJ, Lin YL, Sheu JR, Chen TL (2003) Propofol suppresses macrophage functions and modulates mitochondrial membrane potential and cellular adenosine triphosphate synthesis. Anesthesiology 98(5):1178-1185

8. Hsing CH, Lin MC, Choi PC, Huang WC, Kai JI, Tsai CC, Cheng YL, Hsieh CY, Wang CY, Chang YP, Chen YH, Chen CL, Lin CF (2011) Anesthetic propofol reduces endotoxic inflammation by inhibiting reactive oxygen species-regulated Akt/IKKbeta/ NF-kappaB signaling. PLoS ONE 6(3):e17598. https://doi. org/10.1371/journal.pone.0017598

9. Diekema DJ, Pfaller MA, Schmitz FJ, Smayevsky J, Bell J, Jones RN, Beach M (2001) Survey of infections due to Staphylococcus species: frequency of occurrence and antimicrobial susceptibility of isolates collected in the United States, Canada, Latin America, Europe, and the Western Pacific region for the SENTRY Antimicrobial Surveillance Program, 1997-1999. Clin Infect Dis 32(Suppl 2):S114-S132. https://doi.org/10.1086/320184

10. Gonzalez BE, Martinez-Aguilar G, Hulten KG, Hammerman WA, Coss-Bu J, Avalos-Mishaan A, Mason EO Jr, Kaplan SL (2005) Severe Staphylococcal sepsis in adolescents in the era of community-acquired methicillin-resistant Staphylococcus aureus. Pediatrics 115(3):642-648. https://doi.org/10.1542/peds.2004-2300

11. Labandeira-Rey M, Couzon F, Boisset S, Brown EL, Bes M, Benito Y, Barbu EM, Vazquez V, Hook M, Etienne J, Vandenesch F, Bowden MG (2007) Staphylococcus aureus Panton-Valentine leukocidin causes necrotizing pneumonia. Science 315(5815):11301133. https://doi.org/10.1126/science. 1137165

12. Zecconi A, Scali F (2013) Staphylococcus aureus virulence factors in evasion from innate immune defenses in human and animal diseases. Immunol Lett 150(1-2):12-22. https://doi.org/10.1016/j. imlet.2013.01.004

13. Krishna S, Miller LS (2012) Host-pathogen interactions between the skin and Staphylococcus aureus. Curr Opin Microbiol 15(1):28-35. https://doi.org/10.1016/j.mib.2011.11.003
14. Cho JS, Zussman J, Donegan NP, Ramos RI, Garcia NC, Uslan DZ, Iwakura Y, Simon SI, Cheung AL, Modlin RL, Kim J, Miller LS (2011) Noninvasive in vivo imaging to evaluate immune responses and antimicrobial therapy against Staphylococcus aureus and USA300 MRSA skin infections. J Investig Dermatol 131(4):907-915. https://doi.org/10.1038/jid.2010.417

15. Miller LS, Pietras EM, Uricchio LH, Hirano K, Rao S, Lin H, O'Connell RM, Iwakura Y, Cheung AL, Cheng G, Modlin RL (2007) Inflammasome-mediated production of IL-1beta is required for neutrophil recruitment against Staphylococcus aureus in vivo. J Immunol 179(10):6933-6942

16. Pelegrin P, Barroso-Gutierrez C, Surprenant A (2008) P2X7 receptor differentially couples to distinct release pathways for IL-1beta in mouse macrophage. J Immunol 180(11):7147-7157

17. Chen RM, Chen TG, Chen TL, Lin LL, Chang CC, Chang HC, $\mathrm{Wu} \mathrm{CH}$ (2005) Anti-inflammatory and antioxidative effects of propofol on lipopolysaccharide-activated macrophages. Ann N Y Acad Sci 1042:262-271. https://doi.org/10.1196/annals.1338.030

18. Tanaka T, Kai S, Matsuyama T, Adachi T, Fukuda K, Hirota K (2013) General anesthetics inhibit LPS-induced IL-1beta expression in glial cells. PLoS ONE 8(12):e82930. https://doi. org/10.1371/journal.pone.0082930

19. Peng M, Ye JS, Wang YL, Chen C, Wang CY (2014) Posttreatment with propofol attenuates lipopolysaccharide-induced up-regulation of inflammatory molecules in primary microglia. Inflamm Res 63(5):411-418. https://doi.org/10.1007/s00011-014-0713-9

20. Ploppa A, Kiefer RT, Nohe B, Haeberle HA, Dieterich HJ, Unertl KE, Krueger WA (2006) Dose-dependent influence of barbiturates but not of propofol on human leukocyte phagocytosis of viable Staphylococcus aureus. Crit Care Med 34(2):478-483

21. Ploppa A, Kiefer RT, Nohe B, Haeberle HA, Dieterich HJ, Unertl KE, Durieux ME, Krueger WA (2008) Monocyte phagocytosis of viable Staphylococcus aureus is impaired by barbiturates, but not by propofol. Infection 36(3):220-225. https://doi.org/10.1007/ s15010-007-7240-3

22. Skoutelis A, Lianou P, Papageorgiou E, Kokkinis K, Alexopoulos K, Bassaris H (1994) Effects of propofol and thiopentone on polymorphonuclear leukocyte functions in vitro. Acta Anaesthesiol Scand 38(8):858-862

23. Tassi S, Carta S, Vene R, Delfino L, Ciriolo MR, Rubartelli A (2009) Pathogen-induced interleukin-1beta processing and secretion is regulated by a biphasic redox response. J Immunol 183(2):1456-1462. https://doi.org/10.4049/jimmunol.0900578

24. Asehnoune K, Strassheim D, Mitra S, Kim JY, Abraham E (2004) Involvement of reactive oxygen species in Toll-like receptor 4-dependent activation of NF-kappa B. J Immunol 172(4):2522-2529

25. Baldwin AS Jr (1996) The NF-kappa B and I kappa B proteins: new discoveries and insights. Annu Rev Immunol 14:649-683. https://doi.org/10.1146/annurev.immunol.14.1.649

26. Nishina K, Akamatsu H, Mikawa K, Shiga M, Maekawa N, Obara H, Niwa Y (1998) The inhibitory effects of thiopental, midazolam, and ketamine on human neutrophil functions. Anesth Analg 86(1):159-165 